\title{
MISKONSEPSI SISWA PADA MATERI SISTEM PERSAMAAN LINEAR DUA VARIABEL (SPLDV) BERDASARKAN PROSES BERPIKIR KRITIS DITINJAU DARI KEMAMPUAN AWAL
}

\author{
Rani Pratiwi *)
}

\begin{abstract}
This research aims to determine the misconceptions of students of SMPN 1 Negeri Besar with high initial ability, moderate and low in solving the problem SPLDV based on critical thinking process. The research was a qualitative research. The subjects of the research were taken by using purposive sampling. The method used is test method and interview method equipped with CRI (Certainty of Response Index). The result of the research is that students with high initial ability do not experience misconception at every stage of critical thinking process, students with initial ability is experiencing misconception at analytical stage that is the concept of negative integer operation on both sides, whereas students with low initial ability have misconception at analysis stage and alternative settlement stage.
\end{abstract}

\section{Keywords: Misconceptions, SPLDV, Critical Thinking Process, Initial Ability}

\section{PENDAHULUAN}

Matematika merupakan pelajaran yang menurut sebagian orang pelajaran pasti dengan hasil yang jelas. Adakalanya matematika dinilai sebagai pelajaran yang kaku, hanya membahas hal yang berkaitan pada konsep dan rumus-rumus. Pemahaman tersebut disebabkan sebagian besar pembelajaran matematika di sekolah hanya tentang bagaimana siswa menghafal rumus, mengetahui konsep dan dapat menjawab soal. Selanjutnya saat siswa diberi soal yang berbeda dari contoh yang diberikan, siswa akan merasa kesulitan dalam memecahkan masalah. Oleh karena itu, proses pemecahan masalah sangatlah penting dalam pembelajaran matematika. Sebagaimana yang diung- kapkan Lester (2003) bahwa "Problem solving is the heart of mathematics" yang berarti pemecahan masalah merupakan jantungnya matematika.

Proses pemecahan masalah menuntut proses berpikir lebih kompleks dan kritis karena dengan berpikir kritis dapat memunculkan ide dan mengolah informasi yang ada untuk menemukan pemecahan masalah. Hal ini dipertegas oleh Gibby (2013:150) yang menyatakan "Successful group problem solving processes require critical thinking, leading to the critical understanding needed for deep learning”, yang berarti keberhasilan proses pemecahan masalah membutuhkan kemampuan berpikir kritis, dan pengaruh pemikiran kritis dibutuhkan dalam pembelajaran.

Berpikir kritis menurut Walker dan Finney (dalam Dwi Retnowati, 2016) adalah suatu proses intelektual dalam pembuatan 
konsep, mengaplikasikan, menganalisis, men sintesis, atau mengevaluasi informasi yang didapat.

White (2010:15) membagi 4 tahapan proses berpikir kritis, meliputi: (1) pengenalan (recognition), yaitu siswa memahami masalah kemudian menentukan pokok permasalahan dengan tepat; (2) analisis (analysis), yaitu siswa menganalisis informasi, mengidentifikasi informasi yang relevan dengan masalah masalah disertai alasan yang logis, menentukan langkah pemecahan masalah kemudian membuat kesimpulan; (3) evaluasi (evaluation), yaitu siswa mengevaluasi langkah pemecahan masalah dan kesimpulan yang telah dibuat; (4) alternatif penyelesaian (thinking about alternatives), yaitu siswa menemukan solusi lain dalam pemecahan masalah.

Proses berpikir kritis tidak terlepas dengan penggabungan konsep yang baru saja diterima dengan yang sudah diketahui sebelumnya. Oleh karena itu, kemampuan awal siswa berpengaruh dengan kemampuan berpikir kritis siswa. Sejalan dengan penelitian yang dilakukan Firda Razak (2017) bahwa "terdapat hubungan antara kemampuan awal terhadap kemampuan berpikir kritis matematika siswa ...”.

Kemampuan awal matematika siswa berpengaruh pada ketrampilan siswa dalam memecahkan masalah. Beberapa materi matematika menjadikan kemampuan awal matematika siswa sebagai prasyarat. Jika siswa tidak memiliki kemampuan awal terhadap materi tertentu, siswa akan mengalami kesulitan dalam memecahkan masalah. Kemampuan awal siswa menurut Dewi Purwaningrum dan Sumardi (2016) adalah kemampuan yang telah dipunyai siswa sebelum ia mengikuti pembelajaran.

Kemampuan awal dalam mata pelajaran matematika penting selain untuk mengetahui apakah siswa mempunyai pengetahuan prasyarat juga untuk mengetahui sejauh mana siswa telah mengetahui materi yang akan disajikan sehingga guru dapat merancang pembelajaran lebih baik. Menurut Ega Gradini (2016) pembelajaran yang tidak mempertimbangkan pengetahuan awal siswa mengakibatkan miskonsepsi-miskonsepsi siswa semakin kompleks dan stabil.

Miskonsepsi yang berasal dari siswa dapat berupa prakonsepsi atau konsep awal, pemikiran asosiatif, pemikiran humanistik, penalaran yang tidak lengkap atau salah, intuisi yang salah, kemampuan dan minat belajar siswa (Suparno, 2013:34). Diperjelas oleh Fowler (dalam Suparno, 2005) bahwa miskonsepsi adalah sesuatu yang tidak akurat akan konsep, penggunaan konsep yang salah, klasifikasi contoh yang salah, kekacauan konsep dan hubungan hierarkis konsepkonsep yang tidak benar.

Cara mengidentifikasi siswa mengalami miskonsepsi, atau tidak mengetahui konsep dapat menggunakan suatu metode identifikasi CRI (Certainty of Response 
Index) (Saleem Hasan dan Kelley: 1999). CRI merupakan tingkat keyakinan/kepastian responden dalam menjawab setiap pertanyaan (soal) yang diberikan CRI yang rendah menandakan ketidakyakinan konsep pada diri responden dalam menjawab suatu pertanyaan. Sebaliknya CRI yang tinggi mencerminkan keyakinan dan kepastian konsep yang tinggi pada diri responden.

CRI dikembangkan dengan skala enam (0-5) seperti pada Tabel 1.berikut ini.

Tabel 1. CRI dan Kriterianya

\begin{tabular}{|c|c|}
\hline CRI & KRITERIA \\
\hline 0 & Totally Guesed Answer \\
\hline 1 & Almost Guess \\
\hline 2 & Not Sure \\
\hline 3 & Sure \\
\hline 4 & Almost Certain \\
\hline 5 & Certain \\
\hline
\end{tabular}

Berikut ini ketentuan untuk membedakan antara mengetahui konsep, miskonsepsi dan tidak mengetahui konsep untuk responden secara individu.

Tabel 2. Analisis CRI Berdasarkan Kriteria Jawaban

\begin{tabular}{|l|l|l|}
\hline $\begin{array}{c}\text { Kriteria } \\
\text { Jawaban }\end{array}$ & $\begin{array}{c}\text { CRI Rendah } \\
(<\mathbf{2 , 5})\end{array}$ & $\begin{array}{c}\text { CRI Tinggi } \\
(\mathbf{>} \mathbf{2 , 5})\end{array}$ \\
\hline Jawaban & Jawaban & Jawaban \\
Benar & benar, tetapi & $\begin{array}{l}\text { benar, tetapi } \\
\text { CRI tinggi }\end{array}$ \\
\hline
\end{tabular}

\begin{tabular}{|l|l|l|}
\hline & $\begin{array}{l}\text { Tidak tahu } \\
\text { konsep(lucky } \\
\text { guess) }\end{array}$ & $\begin{array}{l}\text { Mengetahui } \\
\text { konsep } \\
\text { dengan } \\
\text { baik }\end{array}$ \\
\hline $\begin{array}{l}\text { Kriteria } \\
\text { Jawaban }\end{array}$ & $\begin{array}{l}\text { CRI Rendah } \\
(<\mathbf{2 , 5})\end{array}$ & $\begin{array}{l}\text { CRI Tinggi } \\
(>\mathbf{2 , 5})\end{array}$ \\
\hline $\begin{array}{l}\text { Jawaban } \\
\text { Salah }\end{array}$ & $\begin{array}{l}\text { Jawaban } \\
\text { salah dan CRI } \\
\text { rendah } \\
\text { Tidak tahu } \\
\text { konsep }\end{array}$ & $\begin{array}{l}\text { Jawaban } \\
\text { salah, tetapi } \\
\text { CRI tinggi } \\
\text { Terjadi } \\
\text { miskonsepsi }\end{array}$ \\
\hline
\end{tabular}

Salah satu materi matematika yang sering mengalami miskonsepsi karena membutuhkan kemampuan awal pada konsep tertentu sebagai syarat, yaitu Sistem Persamaan Linear Dua Variabel (SPLDV). Materi prasyarat sebelum siswa mendapat materi SPLDV, yaitu materi Operasi Aljabar, dalam hal ini tentang operasi bilangan bulat postif dan negatif, serta mencari nilai suatu variabel.

SPLDV merupakan salah satu materi matematika SMP kelas VIII, materi tersebut masih berkaitan dengan kehidupan seharihari. Hanya saja materi SPLDV ini dianggap sulit oleh siswa kelas IX SMPN 1 Negeri Besar. Berdasarkan observasi di kelas, pada saat guru memberikan materi SPLDV, siswa mengalami beberapa kesulitan. Di antara kesulitan tersebut, kesulitan yang paling banyak dialami siswa, yaitu operasi aljabar dengan variabel yang berbeda, dan operasi pada bilangan bulat positif dan negatif.

Minimnya kemampuan awal siswa terhadap materi sebelumnya seringkali membuat siswa mengarang konsep agar dapat 
memecahkan masalah. Hal tersebut mengakibatkan terjadinya miskonsepsi. Oleh karena itu, perlu diteliti miskonsepsi siswa pada Materi Sistem Persamaan Linear Dua Variabel (SPLDV) Berdasarkan Proses Berpikir Kritis Ditinjau dari Kemampuan Awal. Penelitian ini bertujuan untuk mengetahui miskonsepsi siswa berkemampuan awal tinggi, sedang, dan rendah berdasarkan proses berpikir kritis.

\section{METODE PENELITIAN}

Penelitian ini dilaksanakan di SMPN 1 Negeri Besar pada siswa kelas VIII SMPN 1 Negeri Besar semester genap tahun pelajaran 2017/2018. Jenis penelitian ini merupakan penelitian kualitatif. Teknik pengambilan sampel dilakukan dengan menggunakan purposive sampling berdasarkan kemampuan awal matematika siswa. Subjek dalam penelitian ini, yaitu 7 siswa dengan 2 siswa dengan kemampuan awal tinggi, 2 siswa dengan kemampuan awal sedang, dan 3 siswa dengan kemampuan awal rendah. Instrumen penelitian ini ada dua, yaitu (1) peneliti sebagai instrumen utama. Peneliti melakukan pengumpulan data, mengolah data, dan menganalisis data secara langsung. (2) Intrumen pendukung dalam penelitian ini terdiri dari: (a) Tes Kemampuan awal Matematika berupa tes uraian tentang operasi bilangan bulat, (b) Tes pemahaman konsep SPLDV, dan (c) Pedoman wawancara.
Teknik pengumpulan data dalam penelitian ini dilakukan dengan memberikan tes pemahaman konsep SPLDV. Selanjutnya akan ditanyakan lebih dalam tentang apa yang telah dikerjakan siswa dengan menggunakan pedoman wawancara. Setelah data terkumpul selanjutnya dilakukan analisis dengan teknik CRI (Cetainly of Respon Indeks). Untuk mengvalidasi digunakan triangulasi waktu. Analisis data tersebut melalui tahapan reduksi data, penyajian data, dan penarikan kesimpulan.

\section{HASIL DAN PEMBAHASAN}

Berdasarkan hasil triangulasi dari data penelitian, dapat diperoleh bahwa:

1. Miskonsepsi siswa berkemampuan awal tinggi.

Pada tahap pengenalan, siswa dengan kemampuan awal tinggi tidak mengalami miskonsepsi karena siswa dapat menyebutkan informasi apa saja yang terdapat pada soal, seperti apa yang diketahui dan apa yang ditanyakan secara jelas dengan langsung memisalkan masing-masing variabel.

Pada tahap analisis, siswa dengan kemampuan awal tinggi mampu mengidentifikasi informasi yang dibutuhkan dan memilih cara yang tepat untuk digunakan memecahkan masalah. Siswa mampu menjelaskan secara logis dan yakin untuk menggunakan metode campuran (Eliminasi dan Subtitusi) dalam memecahkan masalah, sehingga dalam hal ini siswa tidak mengalami 
mis- konsepsi. Meskipun dalam beberapa langkah penyelesaian siswa sedikit ragu dalam memberikan penjelasan, akan tetapi siswa masih mengaitkan penjelasannya dengan materi operasi bilangan bulat yang diperoleh sebelumnya.

Tahap evaluasi, pada tahap ini siswa sudah merasa yakin dengan jawabannya sambil menunjukkan lembar hasil pengecekan dan siswa mensubtitusikan hasilnya pada kedua persamaan. Oleh karena itu, pada tahap ini siswa tidak mengalami miskonsepsi karena siswa mensubtitusikan jawabannya pada persamaan pertama maupun yang kedua dan hasilnya benar.

Pada tahap alternatif penyelesaian, siswa tidak mengalami miskonsepsi. Hal tersebut diketahui saat siswa memberikan lembar jawaban sekaligus menjelaskan dengan yakin jika dapat menggunakan metode subtitusi atau metode eliminasi seutuhnya, serta jawaban yang diberikan adalah benar.

2. Miskonsepsi siswa berkemampuan awal matematika sedang.

Tahap pengenalan, pada tahap ini siswa tidak mengalami miskonsepsi karena siswa dapat menyebutkan informasi apa saja yang terdapat pada soal, seperti apa yang diketahui dan apa yang ditanyakan secara jelas.

Pada tahap analisis, siswa mampu mengidentifikasi informasi yang di- butuhkan dan memilih cara yang tepat untuk digunakan memecahkan masalah. Siswa mampu menjelaskan secara logis dan yakin penyebab menggunakan metode campuran (Eliminasi dan Sub- titusi) dalam memecahkan masalah sehingga dalam hal ini siswa tidak mengalami miskonsepsi. Namun, pada saat siswa diwawancara mengapa persamaan awal harus dikali dan disamakan, siswa sempat merasa ragu dengan jawabannya. Meskipun setelah itu siswa dapat memberikan alasan dengan benar, yakni ada variabel yang sama dan dapat dihilangkan/dieliminasi. Dalam hal ini, siswa mengetahui konsep.

Akan tetapi pada saat melakukan subtitusi, siswa tidak mengubah bilangan bulat negatif menjadi bilangan bulat positif saat berpindah ruas. Pada saat diwawancara siswa dengan lancar dan yakin menjelaskan bahwa bilangan negatif meskipun berpindah ruas akan tetap negatif. Untuk memastikan siswa mengalami miskonsepsi atau siswa tidak mengetahui konsep maka diberikan soal tentang operasi bilangan bulat dan bilangan bulat positif akan berpindah ruas. Berdasarkan jawaban siswa, ternyata siswa memberikan jawaban yang benar yakni mengubah bilangan positif menjadi bilangan negatif saat berpindah ruas. Dengan demikian, pada langkah ini siswa tidak mengetahui konsep secara lengkap dan tidak memahaminya. Konsep yang tidak lengkap akan berpengaruh pada saat siswa memecahkan masalah sehingga siswa mengalami miskonsepsi. Sebagaimana yang diungkapkan Ariani dan Widiastuti

(2011:25) bahwa 
"Ketidaklengkapan pengetahuan akan menghambat pengetahuan siswa untuk memecahkan masalah.”

Pada tahap evaluasi, pada tahap ini siswa sudah merasa yakin dengan jawabannya sambil menunjukkan lembar jawaban dan siswa hanya mensub- titusikan hasilnya pada persamaan yang pertama. Siswa menjelaskan karena biasanya jika sudah dicek pada persamaan pertama dan hasilnya benar, tidak perlu dicek pada persamaan yang kedua. Kebiasaan pada saat latihan dengan hanya mengecek pada satu persamaan saja membuat siswa yakin akan jawabannya. Padahal hal tersebut tidak dibenarkan. Oleh karena itu, pada tahap ini siswa mengalami miskonsepsi. Sebagaimana yang dijelaskan Aygor (2012) bahwa siswa yang mengalami miskonsepsi pada saat latihan akan cenderung mengalami miskonsepsi pada saat ujian.

Pada tahap alternatif penyelesaian, siswa tidak mengalami miskonsepsi. Hal tersebut diketahui saat siswa menjelaskan dengan yakin jika dapat menggunakan metode subtitusi. Namun, saat diminta jawaban yang menggunakan metode subtitusi siswa belum mengerjakan.

3. Miskonsepsi siswa berkemampuan awal matematika rendah

Tahap pengenalan, pada tahap ini siswa tidak mengalami miskonsepsi karena siswa dapat menyebutkan informasi apa saja yang terdapat pada soal, seperti apa yang diketahui dan apa yang ditanyakan.
Pada tahap analisis, siswa mampu mengidentifikasi informasi yang dibutuhkan dan memilih cara yang tepat untuk digunakan memecahkan masalah. Siswa mampu menjelaskan secara logis dan yakin penyebab penggunaan metode campuran (Eliminasi dan Subtitusi) dalam memecahkan masalah, sehingga dalam hal ini siswa tidak mengalami miskonsepsi. Akan tetapi pada saat siswa diwawancara mengapa persamaan awal harus dikali dan disamakan, siswa menjelaskan bahwa dari contoh yang sudah diberikan itu harus selalu dikalikan silang dengan angkanya agar sama dan dapat dihilangkan. Dalam hal ini, siswa paham maksud menyamakan konstanta agar dapat dihilangkan/dieliminasi. Namun, siswa beranggapan bahwa itu harus selalu dikalikan silang meskipun konstannya sama. Berarti siswa mengalami miskonsepsi karena siswa mengetahui konsep hanya berdasarkan perkiraannya saja. Ditegaskan oleh Ozkan (2011) bahwa pemahaman yang rendah terhadap suatu konsep menjadikan siswa membuat pengertian sendiri terhadap konsep tersebut.

Selain itu, siswa tidak merubah bilangan bulat negatif menjadi bilangan bulat positif saat berpindah ruas. Pada saat diwawancara siswa dengan malu-malu dan ragu-ragu menjelaskan, bahwa bilangan negatif meskipun berpindah ruas akan tetap negatif. Untuk memastikan siswa mengalami miskonsepsi atau siswa tidak mengetahui konsep maka diberikan soal tentang operasi 
bilangan bulat dan bilangan bulat positif akan berpindah ruas. Berdasarkan jawaban siswa, ternyata siswa memberikan jawaban yang sama, yakni tetap memindahkan bilangan positif menjadi bilangan positif. Peneliti memperjelas kembali dengan menanyakan apakah konsep itu berasal dari apa yang telah diajarkan guru atau hasil pemikiran sendiri, siswa dengan malu-malu mengatakan bahwa itu hasil pemi- kirannya sendiri. Selanjutnya saat di- pertegas seberapa yakin siswa dengan konsep tersebut, siswa menjelaskan bahwa siswa yakin dengan konsep tersebut karena menghasilkan jawaban. Berdasar hasil wawancara tersebut menyatakan bahwa siswa percaya dengan konsep yang dimiliki atau yang biasa digunakan, meskipun konsep tersebut berbeda dari konsep yang benar menurut ahli. Driver dalam Dahar (2012:156) mengemukakan bahwa mis- konsepsi bersifat pribadi, yaitu siswa mengontruksi kebermaknaannya sendiri. Oleh karena itu, siswa mengalami miskonsepsi.

Pada tahap evaluasi, siswa sudah merasa yakin dengan jawabannya. Siswa sudah melakukan evaluasi, akan tetapi siswa hanya mengevaluasi hasil yang sudah ditulisnya dan bukan mengevaluasi dengan mensubtitusikan jawaban pada kedua persamaan. Oleh karena itu, pada tahap ini siswa tidak mengalami miskonsepsi karena siswa tidak paham makna mengevaluasi jawabannya.
Pada tahap alternatif penyelesaian, siswa menjelaskan dengan ragu jika dapat menggunakan metode subtitusi atau metode eliminasi seutuhnya. Akan tetapi pada langkah penyelesaian yang sudah dilakukan siswa melakukan miskonsepsi pada proses operasi bilangan bulat.

\section{SIMPULAN DAN SARAN}

Berdasarkan hasil analisis dan pembahasan yang telah dijelaskan sebelumnya, maka diperoleh simpulan sebagai berikut. Siswa dengan kemampuan awal tinggi pada setiap tahap proses berpikir kritis tahap pengenalan, tahap analisis, tahap evaluasi dan tahap alternatif penyelesaian tidak mengalami miskonsepsi. Meskipun pada tahap analisis siswa sempat ragu memberikan penjelasannya, siswa mampu mengaitkan dengan konsep operasi bilangan bulat yang benar.

Siswa dengan kemampuan awal sedang pada tahap pengenalan tidak mengalami miskonsepsi karena dengan yakin mengungkapkan informasi dengan jelas dan benar. Selanjutnya pada tahap analisis siswa mengalami miskonsepsi konsep operasi bilangan bulat negatif pada kedua ruas. Konsep yang dipahami hanya setengahsetengah meskipun jawaban yang diberikan benar. Miskonsepsi juga terjadi pada tahap evaluasi siswa yakin dengan evaluasi yang biasa dilakukan pada saat latihan meskipun memberikan jawabannya salah. Pada tahap 
alternatif penyelesaian, siswa tidak benar dan bukan dengan meyakini konsep mengalami miskonsepsi.

yang diketahui tanpa konfirmasi dari guru. (3)

Siswa dengan kemampuan awal rendah pada tahap pengenalan tidak mengalami miskonsepsi karena siswa dengan yakin mengungkapkan informasi dengan jelas dan benar. Selanjutnya pada tahap analisis siswa tidak mengalami miskonsepsi. Namun, siswa tidak memahami konsep saat memilih metode yang digunakan untuk memecahkan masalah, dan pada saat menyamakan nilai variabel pada saat proses eliminasi. Kemudian pada konsep operasi bilangan bulat negatif pada kedua ruas, siswa mengalami miskonsepsi. Konsep yang dipahami siswa sejak awal salah. Namun, siswa yakin karena konsep tersebut menghasilkan jawaban yang menurut siswa tersebut benar. Pada tahap evaluasi siswa tidak mengalami miskonsepsi, akan tetapi siswa tidak paham konsep. Pada tahap alternatif penyelesaian, siswa mengalami miskonsepsi. Siswa salah memahami makna alternatif penyelesaian dan dengan yakin akan tetapi malu-malu menunjukkan nilai dari variabel yang diperoleh dan bukan metode lain seperti metode subtitusi atau metode pemfaktoran.

Berdasarkan simpulan yang dibuat maka dapat disarankan hal-hal berikut. (1) Guru dapat mengetes kemampuan awal siswa agar tidak terjadi miskonsepsi pada penyelesaian soal SPLDV. (2) Siswa diharapkan lebih sering melatih proses berpikirnya dengan konspe-konsep yang Bagi peneliti lain yang berminat dapat mencoba untuk menggali lebih lanjut karakteristik miskonsepsi siswa pada jenjang yang berbeda; materi yang berbeda; tinjauan dari ke- cerdasan, kepribadian atau gaya kognitif; atau dapat memberikan solusi pembelajaran menggunakan strategi atau model tertentu agar tidak ada lagi miskonsepsi yang terjadi.

\section{DAFTAR RUJUKAN}

Ariani, N. dan Widiatuti, N. 2011. Meningkatkan Mutu Pendidikan dalam Pembelajaran Aljabar (Cetakan Ke-2). Jakarta: Multazam Mulia Utama.

Aygor, N. 2012. "Misconcepcions in Linear Algebra: The Case of Undergraduate Students". Procedia Social and Behavioral Sciences. (46): 2989 - 2994.

Dahar, Ratna Wilis. 2011. Teori-teori Belajar dan Pembelajaran. Jakarta: PT Gelora Angkasa Pratama.

Gibby, C. 2013. "Critical Thinking Skills in Adult Learners". Journal ARECLS. Vol. 10, No. 1: 147 - 176.

Gradini, Ega. 2016. Miskonsepsi Dalam Pembelajaran Matematika. Sekolah Dasar di Dataran Tinggi Gayo. Jurnal Numeracy. Vol. 3, No. 2: $52-60$.

Lester, F. K., and Kehle, P. E. (2003). From Problem Solving to Modelling: The Evolution of Thinking About Research on Complex Mathematical Activity. In R. Lesh, and H. M. Doerr (Eds.), 
Beyond Constructivism Models and Modelling Perspectives on Mthematical Problem Solving, Learning, and Teaching (pp. 501 - 517). Mahwah, NJ: Lawrence Erlbaum Associates

Ozkan, E. M. 2011. "Misconception in Radicals in High School Mathematics". Procedia-Social and Behavioral Sciences (15): 120-127.

Purwaningrum, Dewi, dan Sumardi. 2016. "Efek Strategi Pembelajaran Ditinjau Dari Kemampuan Awal Matematika Terhadap Hasil Belajar Matematika Kelas XI IPS”. Jurnal Managemen Pendidikan. Vol. 11, No. 2 : 155-167.

Razak, Firda. 2017. "Hubungan Kemampuan Awal Terhadap Kemampuan Berpikir Kritis Matematika pada Siswa Kelas VII SMP Pesantren Immim Putri Minasatene". Jurnal Mosharafa. Vol. 6, No. 1: $117-128$.
Retnowati, Dwi. 2016. "Proses Berpikir Kritis Siswa Kelas IX Farmasi SMK Citra Medika Sragen dalam Pemecahan Masalah Matematika”. Jurnal Elektroni Pembelajaran Matematika. Vol. 4, No. 1: $105-116$.

Saleem Hasan, D. Bagayko, and E. L. Kelley. 1999. "Misconception and the Certainty of Response Index (CRI)". Phys. Education. Vol. 34, No. 5: pp. 294-299.

Suparno Paul. 2005. Filsafat Konstruktivisme Dalam Pendidikan. Yogyakarta : Kanisius.

Suparno, Paul. 2013. Miskonsepsi dan Perubahan Konsep Dalam Pendidikan Fisika. Jakarta: PT Grasindo.

White, D.A. 2010. "Gifted Education: Thinking (With Help From Aristotle) About Critical Thinking". Summer. Vol. 33, No. 3: 14-19. 